\title{
Effects of Purified Myosin Light Chain Kinase on Myosin Light Chain Phosphorylation and Catecholamine Secretion in Digitonin-Permeabilized Chromaffin Cells
}

\author{
Sung A. Lee ${ }^{1}$, Ronald W. Holz ${ }^{1,3}$, and David R. Hathaway ${ }^{2}$
}

Received April 9, 1987

KEY WORDS: myosin; light chain; phosphorylation; catecholamine; chromaffin cell; protein kinase; exocytosis.

ABBREVIATIONS: EGTA, ethyleneglycol-bis-( $(\beta$-aminoethyl ether $)-N, N, N^{\prime}, N^{\prime}$-tetraacetic acid; HEPES, $\mathrm{N}$-2-hydroxyethylpiperazine-N'-2-ethanesulfonic acid; KGEPM, solution containing potassium glutamate, EGTA, PIPES and $\mathrm{MgCl}_{2}$; NE, norepinephrine; PIPES, piperazine-N,-N'-bis-(2-ethanesulfonic acid); PSS, physiological salt solution.

Many non-muscle cells including chromaffin cells contain actin and myosin. The 20,000 dalton light chain subunits of myosin can be phosphorylated by a $\mathrm{Ca}^{2+} /$ calmodulin-dependent enzyme, myosin light chain kinase. In tissues other than striated muscle, light chain phosphorylation is required for actin-induced myosin ATPase activity. The possibility that actin and myosin are involved in catecholamine

${ }^{1}$ Department of Pharmacology, University of Michigan Medical School, M6322 Medical Science I, Ann Arbor, MI 48109-0010.

2 Department of Medicine, Krannert Institute of Cardiology, University of Indiana, Indianapolis, IND 46202.

3 To whom correspondence should be addressed. 
secretion was investigated by determining whether increased phosphorylation in the presence of $\left[\gamma-{ }^{32} \mathrm{P}\right] \mathrm{ATP}$ of myosin light chain by myosin light chain kinase enhances secretion from digitonin-treated chromaffin cells. In the absence of exogenous myosin light chain kinase, $1 \mu \mathrm{M} \mathrm{Ca}^{2+}$ caused a $30-40 \%$ enhancement of the phosphorylation of a $20 \mathrm{kDa}$ protein. This protein was identified on 2 -dimensional gels as myosin light chain by its comigration with purified myosin light chain. Purified myosin light chain kinase $(400 \mu \mathrm{g} / \mathrm{ml})$ in the presence of calmodulin $(10 \mu \mathrm{M})$ caused little or no enhancement of myosin light chain phosphorylation in the absence of $\mathrm{Ca}^{2+}$ in digitonin-treated cells. In the presence of $1 \mu \mathrm{M} \mathrm{Ca}^{2+}$, myosin light chain kinase $(400 \mu \mathrm{g} / \mathrm{ml})$ caused an approximately two-fold increase in myosin light chain phosphorylation in digitonin-treated cells in $5 \mathrm{~min}$. The phosphorylation required permeabilization of the cells by digitonin and occurred within the cells rather than in the medium. Myosin light chain kinase-induced phosphorylation of myosin light chain was maximal at $1 \mu \mathrm{M} . \mathrm{Ca}^{2+}$. Under identical conditions to those of the phosphorylation experiments, secretion was unaltered by myosin light chain kinase. The experiments indicate that the phosphorylation of myosin light chain by myosin light chain kinase is not a limiting factor in secretion in digitonin-treated chromaffin cells and suggest that the activation of myosin is not directly involved in secretion from the cells. The experiments also demonstrate the feasibility of investigation of effects of exogenously added proteins on secretion in digitonin-treated cells.

\section{INTRODUCTION}

At a meeting one year ago Peter Baker overheard one of us (R.W.H.) reminiscing to a colleague how quickly understanding in a new area had developed several years before. He jumped at us and said that one can never look backward. One must always look forward. This was one of the few times Peter Baker was wrong. Now is a time when we must sadly look backwards in order to recognize Pete's contributions to the present and future. For those of us who have had similar interests to Pete, we will sorely miss his enthusiasm and insight.

The demonstration by Peter Baker and Derek Knight that cells with plasma membranes rendered leaky by dielectric breakdown could undergo the complex process of exocytosis $(1,2)$ opened up a powerful new approach for the study of secretion. For the first time one could directly control the intracellular milieu of a functional secretory cell. Their work motivated us and others to examine an alternative method for rendering the plasma membrane leaky utilizing the detergent digitonin $(3,4)$ or saponin $(5)$, each of which interact with membrane cholesterol. The secretory responses of digitonin- and dielectric breakdown-permeabilized cells have identical $\mathrm{Ca}^{2+}$ - and ATP-dependencies. However, an important difference between cells permeabilized by dielectric breakdown and cells permeabilized by digitonin is that the former retain the soluble cytoplasmic protein lactate dehydrogenase $(1,2)$ while the latter are leaky to lactate dehydrogenase $(134-\mathrm{kDa})$ and other cytosolic proteins $(3,4,6)$. Perhaps as a consequence of this difference, the secretory response of cells permeabilized by digitonin is much less stable $\left(t_{1 / 2}\right.$ of $\left.10-15 \mathrm{~min}\right)$ (Holz, R. W., 
unpublished observations) than that of cells permeabilized by dielectric breakdown (stable responses for at least $50 \mathrm{~min}$ ) (2).

The ability of proteins to exit from digitonin-treated cells raises the possibility that exogenous proteins can enter these cells. Indeed, in a recent study we found that trypsin $(27-\mathrm{kDa}$ ) can enter digitonin-treated cells and inhibit secretion (Holz, R. W. and Senter, R. A., unpublished observations). In the following study we have investigated the effects of myosin light chain kinase $(130-\mathrm{kDa})$, an important regulator of nonmuscle myosin, on phosphorylation and secretion in digitonin-treated chromaffin cells.

The possible involvement in exocytosis of contractile proteins which respond to $\mathrm{Ca}^{2+}$ was originally suggested by Douglas and colleagues because of the similar requirement for extracellular $\mathrm{Ca}^{2+}$ of muscle contraction and catecholamine secretion from chromaffin cells $(7,8)$. This notion was supported by the finding that non-muscle cells including chromaffin cells (9) contain contractile proteins such as actin and myosin. Increasing evidence suggests that contractile activity in non-muscle cells, as well as in smooth muscle cells, is regulated by phosphorylation and dephosphorylation of the 20-kDa light chain of myosin by myosin light chain kinase. Myosin light chain phosphorylation in non-muscle cells may serve two important functions: (1) to enhance acto-myosin ATPase activity (10-13) and (2) to stimulate formation of thick filaments (i.e. bundles of myosin) (14). The net effect of phosphorylation would be the formation of structural units fully capable of contractile function. Myosin light chain kinase activity is $\mathrm{Ca}^{2+}$ - and calmodulin-dependent and is probably responsible for the in situ phosphorylation of myosin light chain which occurs in platelets upon activation of secretion by thrombin (15). In adrenal chromaffin cells there is a report that secretion induced by elevated $\mathrm{K}^{+}$is accompanied by phosphorylation of myosin light chain (16). However, cytochalasin B, a disrupter of actin filaments, has little or no direct effect on the process of exocytosis in intact chromaffin cells* (17). Similarly, the microfilament inhibitors cytochalasin $B(1 \mathrm{mM})$, cytochalasin $\mathrm{D}(1 \mathrm{mM})$ and phalloidin (1 mM) had virtually no effect on $\mathrm{Ca}^{2+}$-dependent secretion in chromaffin cells permeabilized by dielectric breakdown in intense electric fields (2). Thus, although $\mathrm{Ca}^{2+}$-dependent phosphorylation of myosin light chain may occur upon secretion in a number of cells, it is unclear whether it plays a role in exocytosis.

In the following work with digitonin-permeabilized chromaffin cells we dernonstrate that myosin light chain kinase specifically phosphorylates intracellular myosin light chain but does not alter $\mathrm{Ca}^{2+}$-dependent catecholamine secretion.

\section{METHODS}

\section{Preparation of Cultured Chromaffin Cells}

Primary dissociated cells from bovine adrenal medulla were prepared as previously described (18), purified by differential plating (19) and maintained as monolayer cultures in Eagle's minimal essential medium (GIBCO, Grand Island,

\footnotetext{
* Cytochalasin $\mathrm{B}(10 \mu \mathrm{M})$ had virtually no effect on $\mathrm{Ca}^{2+}$-dependent secretion stimulated by elevated $\mathrm{K}^{+}$in bovine chromaffin cells. Cytochalasin B $(10 \mu \mathrm{M})$ inhibited $25 \%$ secretion induced by nicotinic receptor activation, probably by interferring with the function of the nicotinic receptor (17).
} 
N.Y.) containing $10 \%$ heat-inactivated fetal calf serum. The culture medium contained 100 units $/ \mathrm{ml}$ of penicillin, $100 \mu \mathrm{g} / \mathrm{ml}$ of streptomycin, $50 \mu \mathrm{g} / \mathrm{ml}$ of gentamicin, and $1.3 \mu \mathrm{g} / \mathrm{ml}$ of Fungizone (Squibb, Princeton, NJ) to prevent bacterial and fungal contamination. The culture medium also contained $10 \mu \mathrm{M}$ cytosine arabinoside to inhibit fibroblast growth. Cells were cultured as monolayers in $6.4 \mathrm{~mm}$ diameter plastic culture wells (Costar, Cambridge, MA) at a density of 500,000 cells per $\mathrm{cm}^{2}$. Plastic culture wells were coated with sterile calfskin collagen (Calbiochem, San Diego, CA) prior to cell plating. Sterile calfskin collagen solution, $100 \mu 1 / \mathrm{cm}^{2}$ of a $50 \mu \mathrm{g} / \mathrm{ml}$ solution (in $0.1 \%$ acetic acid), was applied to each $6.4 \mathrm{~mm}$ diameter well. Acetic acid was allowed to evaporate at room temperature. Experiments were performed 4-11 days after preparation. There were approximately 100 nmole of catecholamine per million cells.

\section{Determination of Catecholamine Secretion from Digitonin-Treated Chromaffin Cells}

Cellular catecholamine stores were labeled by incubation of intact cells with $\left[{ }^{3} \mathrm{H}\right]$ norepinephrine for 2-4 hours. Immediately before an experiment, cells were incubated for 1 hour in physiological salt solution (PSS) containing $145 \mathrm{mM} \mathrm{NaCl}$, $5.6 \mathrm{mM} \mathrm{KCl}, 2.2 \mathrm{mM} \mathrm{CaCl}_{2}, 0.5 \mathrm{mM} \mathrm{MgCl}_{2}, 15 \mathrm{mM}$ HEPES (pH 7.4), $5.6 \mathrm{mM}$ glucose, and $0.5 \mathrm{mM}$ sodium ascorbate unless otherwise indicated. Experiments were initiated by replacing the PSS with a new solution. Cells were rendered leaky by treatment with $20 \mu \mathrm{M}$ digitonin in potassium glutamate buffer solution (KGEPM) containing $139 \mathrm{mM}$ potassium glutamate, $5 \mathrm{mM}$ EGTA, $20 \mathrm{mM}$ PIPES (pH 6.60), $1 \mathrm{mM} \mathrm{MgCl}, 1 \mathrm{mM} \mathrm{MgATP}$, and various amounts of $\mathrm{CaCl}_{2}$ to yield buffered $\mathrm{Ca}^{2+}$ concentrations of $0-10 \mu \mathrm{M}$. KGEPM was modified as indicated in various experiments. Secretion was determined by measuring the percentage of total cellular radioactivity released into the medium (13). All experiments were performed at $25^{\circ} \mathrm{C}$.

\section{Protein Phosphorylation in Digitonin-Treated Chromaffin Cells and Intact Cells}

Intracellular phosphorylation in digitonin-treated cells was determined by incubation of cells in $6.4 \mathrm{~mm}$ diameter wells in KGEPM solution containing $20 \mu \mathrm{M}$ digitonin, various concentrations of $\mathrm{CaCl}_{2}, 2 \mathrm{mM} \mathrm{MgCl}$ and $1 \mathrm{mM}\left[\gamma^{32} \mathrm{P}\right] \mathrm{ATP}$ $(200 \mu \mathrm{Ci} / \mathrm{ml})$ and $10 \mu \mathrm{M}$ calmodulin unless otherwise indicated. Experiments were terminated by replacing the medium with $0.15 \mathrm{ml}$ of solution containing $3 \%$ sodium dodecyl sulfate (SDS), $6 \% \beta$-mercaptoethanol, $5 \%$ (w/v) glycerol, $62 \mathrm{mM}$ Tris-Cl ( $\mathrm{pH}$ 6.8 ) and $0.17 \mathrm{mg} / \mathrm{ml}$ bromophenol blue. Cellular proteins were further denatured by incubation at $95^{\circ} \mathrm{C}$ for $5 \mathrm{~min}$. Aliquots $(0.1 \mathrm{ml})$ of the denatured cell lysates were analyzed for phosphoprotein by SDS-polyacrylamide (5-20\% gradient) slab gel electrophoresis using the procedure originally developed by Laemmli (20). After electrophoresis, gels were stained with Coomassie brilliant blue $\mathrm{R}$, dried, and exposed to Kodak X-Omat AR-2 film for autoradiography.

For two-dimensional gel electrophoresis of phosphoproteins in digitonin-treated cells, cells were incubated in the presence of $2-4 \mathrm{mCi} / \mathrm{ml}\left[\gamma^{32} \mathrm{P}\right] \mathrm{AT}$.P and the 
incubation terminated by replacing the medium with $0.04 \mathrm{ml}$ of solution containing 9.5 M urea, 2\%(w/v) Nonidet P-40, 5\% $\beta$-mercaptoethanol and $2 \%$ ampholytes [comprised of $1.6 \%$ Bio-Lyte (pH range 5 to 7; Bio-Rad, Richmond, CA) and $0.4 \%$ Ampholine ( $\mathrm{pH}$ range 3.5 to 9.5; LKB, Gaithersburg, MD)]. Aliquots $(20 \mu 1)$ were subjected to isoelectric focusing followed by SDS-polyacrylamide (5-20\% gradient) gel electrophoresis according to O'Farrell (21). Isoelectric focusing was performed using $11.5 \mathrm{~cm}$ tube gels of $2.0 \mathrm{~mm}$ diameter.

The $\mathrm{pH}$ gradient of isoelectric focusing gels was determined by equilibrating $0.5 \mathrm{~cm}$ segments of the tube gel in $2 \mathrm{ml}$ of degassed and deionized water in $10 \times 75 \mathrm{~mm}$ glass test tubes covered with parafilm for $4-5$ hours with occasional vortexing (21). The gradient was approximately linear from $\mathrm{pH} 4.5$ to 7.0 . The apparent pIs of phosphoproteins resolved in two-dimensional gels were determined from the $\mathrm{pH}$ gradient curve by comparison of the distance of each spot from the acidic end. Molecular weights were determined by comparison to positions of standard proteins (Bio-Rad) which were visualized by Coomassie blue staining. The molecular weight marker proteins used were lysozyme $(14,400 \mathrm{Da})$, soybean trypsin inhibitor $(21,500 \mathrm{Da})$, carbonic anhydrase $(31,000 \mathrm{Da})$, ovalbumin $(45,000 \mathrm{Da})$, bovine serum albumin $(66,200 \mathrm{Da})$, and phosphorylase B $(92,500 \mathrm{Da})$. Autoradiographs of onedimensional SDS-polyacrylamide gel electrophoresis were analyzed by densitometric quantitation using an EC 910 densitometer (EC-Apparatus Co., St Petersburg, FL). The quantitation was performed over a range where the densities increased proportionally with the amount of phosphorylated protein. Peak heights from densitometric tracings were measured after subtracting background densities in neighboring regions of the tracings as described previously (22), and expressed in arbitrary units.

\section{Protein Purification}

Myosin light chain kinase from chicken gizzard was purified to homogeneity according to Hathaway et al. (23). For identification of phosphorylated myosin light chain, myosin from bovine aorta was purified and phosphorylated with myosin light chain kinase according to Sellers et al. (11). The phosphorylated myosin was precipitated with $5 \%$ TCA. The precipitate was washed with acetone, and lyophilized. The phosphorylated myosin was dissolved in isoelectric focusing solution containing $9.5 \mathrm{M}$ urea, $2 \%(\mathrm{w} / \mathrm{v})$ Nonidet P-40, $5 \% \beta$-mercaptoethanol and $2 \%$ ampholytes. Insoluble material (i.e. mostly myosin heavy chain) was removed by sedimentation.

\section{Data}

Data were expressed as mean \pm standard error of the mean (SEM). Error bars smaller than the symbols or lines used in the figures were omitted. Significance was determined by Student's $t$-test. 


\section{RESULTS AND DISCUSSION}

\section{The Effects of Exogenous Myosin Light Chain Kinase on Protein Phosphorylation in Digitonin-Permeabilized Cells}

Two-dimensional SDS-polyacrylamide gel electrophoresis of proteins phosphorylated by exogenous, purified myosin light chain kinase in digitonin-treated cells revealed that the enzyme enhanced the $\mathrm{Ca}^{2+}$-dependent phosphorylation of 2 proteins of similar mobility (Fig. 1). The most prominent spot had a molecular mass of $20-\mathrm{kDa}$ and a pI of 5.02 (indicated by arrowhead in Fig. 1). A spot with a slightly lower molecular mass of $19.6-\mathrm{kDa}$ and the same pI was phosphorylated, but to a much smaller degree. The phosphorylation of other proteins in response to myosin light

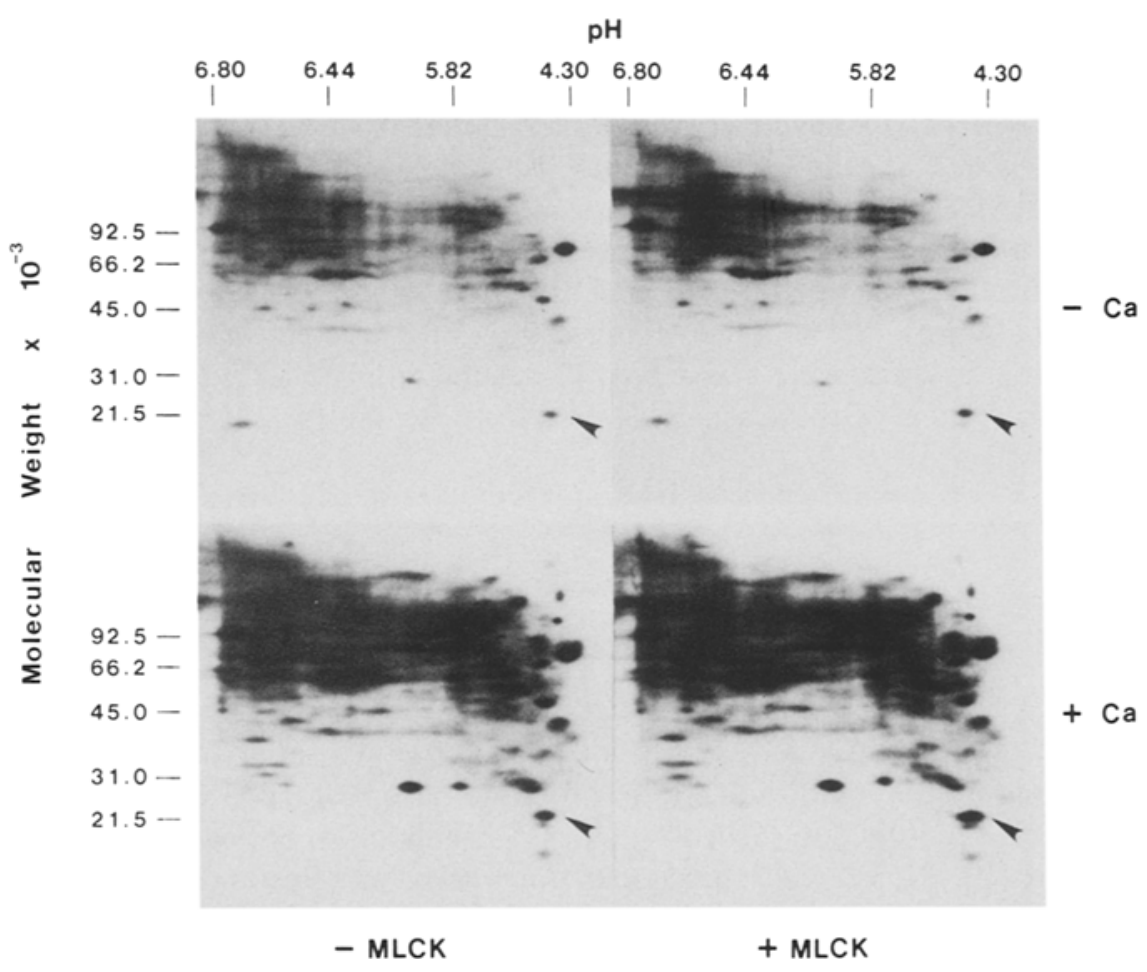

Fig. 2. Two-dimensional SDS-polyacrylamide gel electrophoresis of proteins phosphorylated by purified myosin light chain kinase in digitonin-treated chromaffin cells. Chromaffin cells were incubated in KGEPM solution containing $20 \mu \mathrm{M}$ digitonin, $2 \mathrm{mM} \mathrm{MgCl}, 1 \mathrm{mM}$ dithiothreitol, $50 \mu \mathrm{g} / \mathrm{ml}$ leupeptin, $36 \mu \mathrm{g} / \mathrm{ml}$ BSA (fatty acid-free), $10 \mu \mathrm{M}$ calmodulin, 0 or $1 \mu \mathrm{M} \mathrm{Ca}{ }^{2+}$, 0 or $400 \mu \mathrm{g} / \mathrm{ml}$ purified myosin light chain kinase and $1 \mathrm{mM}\left[\gamma^{32} \mathrm{P}\right] \mathrm{ATP}$. After $7 \mathrm{~min}$, cells were washed briefly $(15 \mathrm{sec})$ with ice-cold solution $(300 \mathrm{mOsm})$ containing $50 \mathrm{mM}$ sodium pyrophosphate, $40 \mathrm{mM}$ sodium fluoride, $5 \mathrm{mM}$ EGTA, $5 \mathrm{mM}$ EDTA, $5 \mathrm{mM}$ HEPES (pH 7.0) and $50 \mu \mathrm{g} / \mathrm{ml}$ leupeptin, and then, urea- and Nonidet P-40-containing solution was added. Cell lysates were subjected to isoelectric focusing followed by SDS-polyacrylamide (5-20\% gradient) gel electrophoresis and subsequent autoradiography. Arrowheads indicate the $20-\mathrm{kDa}$ protein which was identified as myosin light chain (see text). MLCK refers to exogenous, purified myosin light chain kinase. 
chain kinase was not detected. The proteins with molecular mass of $20-\mathrm{kDa}$ and $19.6-$ $\mathrm{kDa}$ were also phosphorylated, but to a lesser degree, in the absence of exogenous myosin light chain kinase upon addition of $1 \mu \mathrm{M} \mathrm{Ca}^{2+}$. The molecular weight and $\mathrm{pI}$ of the prominent spot were virtually identical with those of smooth muscle myosin light chain which has a molecular weight of $20-\mathrm{kDa}$ and a pl of 5.04 (24).

The mobilities of the doublet proteins in 2-dimensional gels were directly compared with those of phosphorylated 20,000 dalton myosin light chain prepared by phosphorylation of purified bovine aortic myosin with myosin light chain kinase and $\left[\gamma-{ }^{32} \mathrm{P}\right]$ ATP (see Methods). $\left[{ }^{32} \mathrm{P}\right]$ Phosphorylated myosin light chain was added to a tissue sample (in urea- and Nonidet P-40-containing solution) from permeabilized cells which had been incubated with $\left[\gamma-{ }^{32} \mathrm{P}\right] \mathrm{ATP}$ in the absence of $\mathrm{Ca}^{2+}$. The $\left[{ }^{32} \mathrm{P}\right]$-labeled myosin light chains were resolved into a major phosphorylated protein of $20-\mathrm{kDa}$ and a minor phosphorylated protein of $19.6-\mathrm{kDa}$ which exactly comigrated with the doublet from the chromaffin cells (data not shown). The purified myosin contained a third protein of $18.5-\mathrm{kDa}$ with a $\mathrm{pI}$ of 4.7 which was phosphorylated to an even smaller degree than the 19.6-kDa protein. Thus, the predominant phosphorylated species was of molecular mass $20 \mathrm{kDa}(\mathrm{pI}=5.02)$. The various satellite bands may have resulted from proteolysis, multiple site phosphorylation or protein modification (25).

The phosphorylation of myosin light chain induced by $\mathrm{Ca}^{2+}$ and myosin light chain kinase could be detected in one-dimensional SDS-polyacrylamide gels and quantitated by densitometry (Fig. 2). The gels did not resolve the 19.6-kDa form of myosin light chain. The quantitation may overestimate to some degree the phosphorylation of myosin light chain in the absence of $\mathrm{Ca}^{2+}$ because of the presence of a phosphorylated protein of molecular mass $19 \mathrm{kDa}$ and $\mathrm{pI} 6.70$ (Fig. 1). Myosin light chain phosphorylation was not detected in cells which were not permeabilized with digitonin (data not shown).

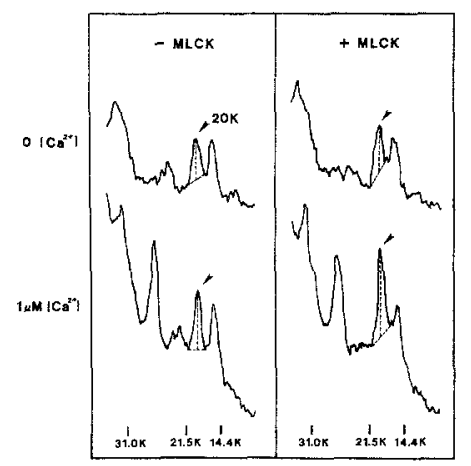

Fig. 2. Densitometric quantitation of the effects of purified myosin light chain kinase on phosphorylation of a $20-\mathrm{kDa}$ protein identified as myosin light chain in digitonin-treated chromaffin cells. Chromaffin cells were incubated in KGEPM solution containing $20 \mu \mathrm{M}$ digitonin, $2 \mathrm{mM} \mathrm{MgCl}_{2}, 50 \mu \mathrm{g} / \mathrm{ml}$ leupeptin, $40 \mu \mathrm{M}$ dithiothreitol, $0.5 \mathrm{mg} / \mathrm{ml}$ BSA (fatty acid-free), $10 \mu \mathrm{M}$ calmodulin, 0 or $1 \mu \mathrm{M} \mathrm{Ca}^{2+}, 0$ or $400 \mu \mathrm{g} / \mathrm{ml}$ purified myosin light chain kinase and $1 \mathrm{mM}\left[\gamma^{32} \mathrm{P}\right]$ ATP. After $5 \mathrm{~min}$, the phosphorylation was terminated by replacing the medium with SDS-containing solution. Phosphoproteins were subjected to onedimensional SDS-polyacrylamide (5-20\% gradient) gel electrophoresis and subsequent autoradiography as described in Methods. MLCK refers to exogenous, purified myosin light chain kinase.

\section{Phosphorylated Myosin Light Chain is Intracellular}

Digitonin-treated chromaffin cells are permeable to proteins and some phosphorylation of myosin light chain occurred extracellularly. Nevertheless, the phosphorylated myosin light chain which was detected in the experiments was intracellular because only proteins associated with the cell monolayer were 
investigated. Phosphorylated myosin light chain in the medium which remained with the monolayer could not account for the phosphorylated myosin light chain which was detected, because at least $95 \%$ of the extracellular medium was removed in experiments in which cells were not washed (e.g. Figs 2 and 3 ) and greater than $99.5 \%$ of the original medium was removed from cells washed once with buffer (Fig. 1). Because $70 \%$ of the phosphorylated myosin light chain was intracellular after a $15 \mathrm{~min}$ incubation with myosin light chain kinase, $\mathrm{Ca}^{2+}$ and $\left[\gamma-{ }^{32} \mathrm{P}\right]$ ATP (data not shown), the phosphorylated myosin light chain the small amount of contaminating extracellular medium associated with the cells could contribute no more than 0.15 $1.5 \%$ to the phosphorylated myosin light chain which was detected.

\section{Effects of Exogenous Myosin Light Chain Kinase on $\mathrm{Ca}^{2+}$-Dependent Myosin Light Chain Phosphorylation and Catecholamine Secretion in Permeabilized Cells}

Phosphorylated myosin light chain was detected after 5 and $15 \mathrm{~min}$ in the absence of both $\mathrm{Ca}^{2+}$ and exogenous myosin light chain kinase (Fig. 3A and B). The response of phosphorylation to $\mathrm{Ca}^{2+}$ was somewhat different at the two times. In cells

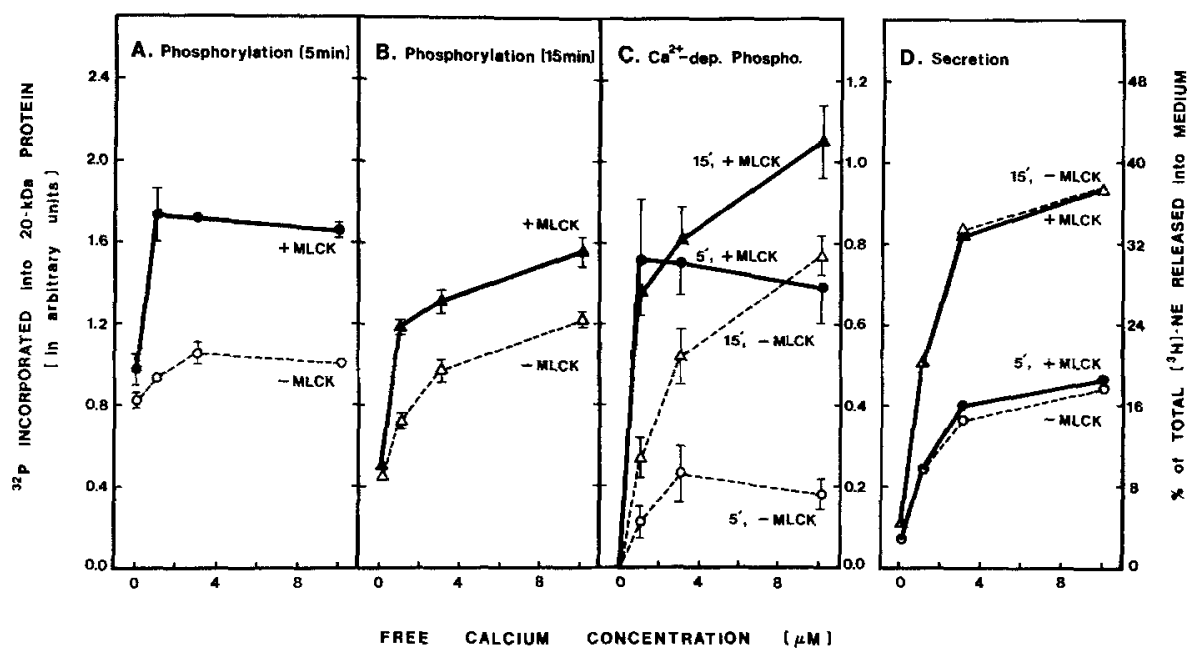

Fig. 3. Effects of purified myosin light chain kinase on $\mathrm{Ca}^{2+}$ dose-response for myosin light chain phosphorylation and catecholamine secretion in digitonin-treated chromaffin cells $\mathrm{A}, \mathrm{B}$ and $\mathrm{C}$. Phosphorylation: Chromaffin cells were incubated in KGEPM solution containing $20 \mu \mathrm{M}$ digitonin, $2 \mathrm{mM} \mathrm{MgCl}, 1 \mathrm{mM}$ dithiothreitol, $50 \mu \mathrm{g} / \mathrm{ml}$ leupeptin, $0.5 \mathrm{mg} / \mathrm{ml} \mathrm{BSA}$ (fatty acid-free), $10 \mu \mathrm{M}$ calmodulin, various concentrations of $\mathrm{Ca}^{2+}, 0$ or $400 \mu \mathrm{g} / \mathrm{ml}$ purified myosin light chain kinase (MLCK) and $1 \mathrm{mM}\left[\gamma^{32} \mathrm{P}\right] \mathrm{ATP}$. After 5 (A) or $15 \mathrm{~min}$ (B) phosphorylation was terminated by replacing the medium with SDS-containing solution. Phosphoproteins were subjected to onedimensional SDS-polyacrylamide $(5-20 \%$ gradient $)$ gel electrophoresis and subsequent autoradiography. Phosphorylation of myosin light chain was analyzed by densitometric quantitation of autoradiographs. $\mathrm{Ca}^{2+}$-dependent phosphorylation of myosin light chain is shown in (C). (D), Secretion: Chromaffin cells which had been prelabeled with $\left[{ }^{3} \mathrm{H}\right]$ norepinephrine were incubated in KGEPM solution containing $20 \mu \mathrm{M}$ digitonin, $2 \mathrm{mM} \mathrm{MgATP}, 1 \mathrm{mM}$ dithiothreitol; $50 \mu \mathrm{g} / \mathrm{ml}$ leupeptin, $0.5 \mathrm{mg} / \mathrm{ml}$ BSA (fatty acid-free), $10 \mu \mathrm{M}$ calmodulin, various concentrations of $\mathrm{Ca}^{2+}$ and 0 or $400 \mu \mathrm{g} / \mathrm{ml}$ purified myosin light chain kinase. The percentage of $\left[{ }^{3} \mathrm{H}\right]$ norepinephrine released into medium was determined after 5 or $15 \mathrm{~min}$. Each group contained 3 wells in A-D. 
incubated for $5 \mathrm{~min}$ in the absence (or presence) of exogenous myosin light chain kinase, $\mathrm{Ca}^{2+}$-dependent phosphorylation was maximal by $1 \mu \mathrm{M} \mathrm{Ca}{ }^{2+}$. In cells incubated for $15 \mathrm{~min}$ in the absence (or presence) of exogenous myosin light chain kinase, myosin light chain phosphorylation continued to increase between 1 and $10 \mu \mathrm{M} \mathrm{Ca}^{2+}$. It is possible that by $15 \mathrm{~min}$, but not by $5 \mathrm{~min}$, an endogenous, $\mathrm{Ca}^{2+}$ dependent protein kinase contributed to the phosphorylation of myosin light chain which was sensitive to $\mathrm{Ca}^{2+}$ concentrations greater than $1 \mu \mathrm{M} \mathrm{Ca}^{2+}$.

Exogenous myosin light chain kinase enhanced the $\mathrm{Ca}^{2+}$-dependent phosphorylation of myosin light chain with maximal enhancement occurring at $1 \mu \mathrm{M}$ $\mathrm{Ca}^{2+}$ at 5 or $15 \mathrm{~min}$ (Figs $3 \mathrm{~A}, \mathrm{~B}$ and $\mathrm{C}$ ). The enhancement by myosin light chain kinase of phosphorylation of myosin light chain was larger in cells incubated for 5 min than for $15 \mathrm{~min}$ at all $\mathrm{Ca}^{2+}$ concentrations, perhaps because there was more intracellular myosin light chain after $5 \mathrm{~min}$ than after $15 \mathrm{~min}$. After $5 \mathrm{~min}$ myosin light chain kinase increased 2-fold the total phosphorylation of myosin light chain at $1 \mu \mathrm{M} \mathrm{Ca}^{2+}(\mathrm{Fig}$. $3 \mathrm{~A}$ ) and increased $\mathrm{Ca}^{2+}$-dependent phosphorylation 3 to 6-fold (Fig. 3C).

In a companion secretion experiment, exogenous myosin light chain kinase had little or no effect on catecholamine secretion at 5 or $15 \mathrm{~min}$ at various $\mathrm{Ca}^{2+}$ concentrations (Fig. 3D). Exogenous myosin light chain kinase $(350-400 \mu \mathrm{g} / \mathrm{ml}) \mathrm{did}$ not alter secretion in 6 of 6 experiments.

The phorbol ester 12-O-tetradecanoylphorbol 13-acetate (TPA) which activates protein kinase $\mathrm{C}(26)$ enhances $\mathrm{Ca}^{2+}$-dependent secretion from digitonin-treated chromaffin cells (27). The presence of myosin light chain kinase $(400 \mu \mathrm{g} / \mathrm{ml})$ did not alter TPA-induced secretion from digitonin-permeabilized cells (data not shown). Thus, secretion that was enhanced by activation of protein kinase $\mathrm{C}$ was also not altered by myosin light chain kinase.

In conclusion, the absence of effects on secretion of phosphorylation of myosin light chain by myosin light chain kinase suggests that the interaction of actin and myosin is not a rate limiting step in $\mathrm{Ca}^{2+}$-dependent secretion in chromaffin cells. However, these experiments do not eliminate the possibility that cytoskeletal proteins are involved in other processes connected with secretion such as granule movement or retrieval of the chromaffin granule membrane after exocytosis. Indeed, $\mathrm{Ca}^{2+}$ independent disassembly of actin (28) and $\mathrm{Ca}^{2+}$-dependent patching of fodrin (29) have been observed upon nicotinic stimulation of chromaffin cells.

\section{ACKNOWLEDGEMENTS}

We are grateful to Dr Michael J. Welsh (Department of Anatomy and Cell Biology, University of Michigan Medical School) for giving us purified calmodulin. This work was supported by grants to RWH from the Public Health Service (R01-AM27959) and from the National Science Foundation BNS82-11493 and to DRH from the Public Health Service (P01-HL-060308 and R01-HL-32947). RWH is an Established Investigator of the American Heart Association. 


\section{REFERENCES}

1. Baker, P. F. and Knight, D. E. (1978). Nature 276:620-622.

2. Knight, D. E. and Baker, P. F. (1982). J. Membrane Biol. 68:107-140.

3. Dunn, L. A. and Holz, R. W. (1983). J. Biol. Chem. 258:4989-4993.

4. Wilson, S. P. and Kirshner, N. (1983). J. Biol. Chem. 258:4994-5000.

5. Brooks, J. C. and Treml, S. (1983). J. Neurochem. 40:468-473.

6. Kelner, K., Morita, K., Rossen, J. S. and Pollard, H. B. (1986). Proc. Nat. Acad. Sci. (USA) 83:29983002 .

7. Douglas, W. W. and Rubin, R. R. (1964). J. Physiol. (Lond.) 175:231-241.

8. Douglas, W. W. (1975). In; Handbook of Physiology Endocrinology, Sec. 7, Vol. 6 (H. Blaschko, G. Sayers and A. D. Smith, Eds.), American Physiological Society, Washington DC, pp. 367-388.

9. Trifaro, J. M. (1978). Neuroscience 3:1-24.

10. Sherry, J. M.F., Gorecka, A., Aksoy, M. O., Dabrowska, R. and Hartshorne, D. J. (1978). Biochemistry 17:4411-4418.

11. Sellers, J. R., Pato, M. D. and Adelstein, R. S. (1981). J. Biol. Chem. 256:13137-13142.

12. Adelstein, R. S. and Eisenberg, E. (1980). Annu. Rev. Biochem. 49:921-956.

13. Hartshorne, D. J. and Siemankowski, R. F. (1981). Annu. Rev. Physiol. 43:519-530.

14. Scholey, J. M., Taylor, K. A. and Keadrick-Jones, J. (1980). Nature 287:233-235.

15. Daniel, J. L., Malish, I. R and Holmsen, H. (1981). J. Biol. Chem. 256:7510-7514.

16. Trifaró, J. M., Lee, R. W. H., Kenigsberg, R. L. and Coté, A. (1982). In: Advances in the Biosciences (F. Izumi et al. Eds.), Vol. 36, pp. 151-158.

17. Schneider, A. S., Cline, H. T., Rosenheck, K. and Sonenberg, M. J. (1981). J. Neurochem. 37:567-575.

18. Holz, R. W., Senter, R. A. and Frye, R. A. (1982). J. Neurochem. 39:635-646.

19. Waymire, J.C., Bennett, W. F., Boehme, R., Hanteins, L., Gilmer-Waymire, K. and Haycock, J. (1983). J. Neurosci. Methods 7:329-351.

20. Laemmli, U. K. (1970). Nature 227:680-685.

21. O'Farrell, P. H. (1975). J. Biol. Chem. 250:4007-4021.

22. Ueda, T., Maeno, H. and Greengard, P. (1973). J. Biol. Chem. 248:8295-8305.

23. Hathaway, D. R., Konicki, M. V. and Coolican, S. A. (1985). J. Mol. Cell. Cardiol. 17:841-850.

24. Haeberle, J. R., Hott, J. W. and Hathaway, D. R. (1984). Biochem. Biophys. Acta 790:78-86.

25. Ikebe, M. and Hartshorne, D. J. (1985). J. Biol. Chem. 260:10027-10031.

26. Castagna, M., Takai, Y., Kaibuchi, K., Sano, K., Kikkawa, U. and Nishizuka, Y. (1982). J. Biol. Chem. 257:7847-7851.

27. Pocotte, S. L., Frye, R. A., Senter, R. A., TerBush, D. R., Lee, S. A. and Holz, R. W. (1985). Proc. Natl. Acad. Sci. USA 82:930-934.

28. Cheek, T. R. and Burgoyne, R. D. (1986). FEBS Lett. 207:110-114.

29. Perrin, D. and Aunis, D. (1985). Nature 315:589-592. 